International Journal of Linguistics, Literature and Translation

ISSN: 2617-0299 (Online); ISSN: 2708-0099 (Print)

DOI: $10.32996 / \mathrm{ijllt}$

Journal Homepage: www.al-kindipublisher.com/index.php/ijllt

\title{
The Meranaw In Weddings: Understanding Pragmatics
}

\author{
Bai Salam Macapia Ibrahim 8 (D) \\ English Department, Mindanao State University, Marawi City, Philippines
}

$\checkmark$ Corresponding Author: Bai Salam Macapia Ibrahim, E-mail: baisalam.ibrahim@msumain.edu.ph

ARTICLE INFORMATION ABSTRACT

Received: March 14, 2021

Accepted: April 22, 2021

Volume: 4

Issue: 4

DOI: $10.32996 / i j \mid l t .2021 .4 .4 .30$

\section{KEYWORDS}

Meranaw language, pragmatics, Meranaw wedding, semiotics
The Meranaw people are fond of "pananaroon" or proverbs. Most of the old folks use these proverbs to express their thoughts toward a situation. Meranaw and nonmeranaw alike who are not exposed to the Meranaw community may misunderstood and misinterpret this Meranaw sarcasm as expressed through proverbs. By using qualitative analytical approach, this research paper aims to unveil the Meranaw pragmatics by analyzing and semiotically interpreting video recorded Meranaw speech acts delivered in Meranaw wedding gathering along with the reactions of the people involved in the interaction. Some of the aspects of language studied in pragmatics which are also be considered in studying the data include diexis, presupposition,performative, and implicature. The study shows how junctures plays a vital role in understanding pananaroon. Morever, the study shows that the Meranaw people are one of those whose language is very powerful in the society. It will take an outsider to immerse himself with the folks to fully understand what a word means and or a gesture means.

\section{Introduction}

\begin{abstract}
Na o tanto ka a paginged sa darinayan kapparan,
Na bangoningka sa pandi a gandamato damdag

Ka apayo dibo tanto, na payongang ko skawn

Sa benaning di kumlas a gadong di kumayakas...
\end{abstract}

The Meranaw people are fond of "pananaroon" or proverbs just like the above lines. This lines talk about courtship. A woman expressing this means the woman is challenging the man to vocally express his intention of marriage by going up to the woman's house and asking for her hands. For a non-meranaw or even a meranaw who is not exposed to such way or manner of expressing a thought may misunderstand or misinterpret the language and the meaning of the above stanza. The way the woman expresses her thought, the words stated itself, the gestures and facial expressions of the woman and her voice and pitch alone may mean so many things. But, for a man who has outstanding pragmatic competence, knows what to do, what to say and how to respond. Understanding the Meranaw people and their language requires pragmatics.

Pragmatics refers to the social language skills we use in our daily interactions with others. They include what we say, how we say it, our body language and whether it is appropriate to the given situation.Pragmatic language skills involve being able to use social contextual cues in order to understand a speaker's meaning and to attain social goals through effective communication with others. Pragmatic language is considered an important contributor to the development of communicative competence (Leinonen,Ryder, Ellis, \& Hammond, 2003). Eales (1993) argued that pragmatic language deficits could affect a wide range of areas of functioning and should be related to a number of disorders.

Pragmatic skills are vital for communicating our personal thoughts, ideas and feelings. Children, adolescents and adults with poor pragmatic skills often misinterpret other's communicative intent and have difficulty responding appropriately either verbally

\section{K C AL-KINDI CENTER \\ $\mathbf{R}$ D FOR RESEARCH AND DEVELOPMENT}

Your gateway to world-class research

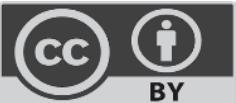

Published by Al-Kindi Center for Research and Development, London, United Kingdom. Copyright (c) the author(s). This open access article is distributed under a Creative Commons Attribution (CC-BY) 4.0 license 
or non-verbally (Belinda Hills Associates).

Examples of pragmatic skills are conversational skills, Asking for, giving and responding to information, Turn taking, Eye contact, Asking questions, Avoiding repetitious/redundant information, Asking for clarification, Using language of a given peer group, Using humour, Using appropriate strategies for gaining attention and interrupting, Asking for help or offering help appropriately, Offering/responding to expressions of affection appropriately etc. Other skills include Non-Verbal Skills such as facial expressions, Body language, Intonation of voice and Body distance and personal space.

This research paper aims to unveil the Meranaw Pragmatics by analyzing and semiotically interpreting Meranaw speech acts delivered in Meranaw wedding gathering along with the reactions of the people involved in the interaction. Some of the aspects of language studied in pragmatics that will also be considered in studying the data include:

1. Deixis. The meaning 'pointing to' something. In verbal communication however, deixis in its narrow sense refers to the contextual meaning of pronouns, and in its broad sense, what the speaker means by a particular utterance in a given speech context.

2. Presupposition. This refers to the logical meaning of a sentence or meanings logically associated with or entailed by a sentence.

3. Performative: This implies that by each utterance a speaker not only says something but also does certain things: giving information, stating a fact or hinting an attitude. The study of performatives led to the hypothesis of Speech Act Theory that holds that a speech event embodies three acts: a locutionary act, an illocutionary act and a perlocutionary act (Austin, 1962; Searle, 1969).

4. Implicature. This refers to an indirect or implicit meaning of an utterance derived from context that is not present from its conventional use.

Moreover, this research paper aimed to answer the following questions:

1. What pragmatic skills are present in the collected speech acts of Meranaw weddings in verbal cues?

2. What pragmatic skills are present in the collected speech acts of Meranaw weddings in non-verbal cues? 3.

\section{Literature review}

\subsection{Theories on Pragmatics}

Shaozhong Liu (2005) defined pragmatics as a subfield of linguistics developed in the late 1970s. It studies how people comprehend and produce a communicative act or speech act in a concrete speech situation which is usually a conversation (hence *conversation analysis). It distinguishes two intents or meanings in each utterance or communicative act of verbal communication. One is the informative intent or the sentence meaning, and the other the communicative intent or speaker meaning (Leech, 1983; Sperber and Wilson, 1986). The ability to comprehend and produce a communicative act is referred to as pragmatic competence (Kasper, 1997) which often includes one's knowledge about the social distance, social status between the speakers involved, the cultural knowledge such as politeness, and the linguistic knowledge explicit and implicit.

Although pragmatics is a relatively new branch of linguistics, research on it can be dated back to ancient Greece and Rome where the term pragmaticus' is found in late Latin and pragmaticos' in Greek, both meaning of being practical'. Modern use and current practice of pragmatics is credited to the influence of the American philosophical doctrine of pragmatism. The pragmatic interpretation of semiotics and verbal communication studies in Foundations of the Theory of Signs by Charles Morris (1938), for instance, helped neatly expound the differences of mainstream enterprises in semiotics and linguistics. For Morris, pragmatics studies the relations of signs to interpreters', while semantics studies the relations of signs to the objects to which the signs are applicable', and syntactics studies the formal relations of signs to one another.' By elaborating the sense of pragmatism in his concern of conversational meanings, Grice (1975) enlightened modern treatment of meaning by distinguishing two kinds of meaning, natural and non-natural (Social Research Glossary, qualityresearchinternational.com).

Throughout its development, pragmatics has been steered by the philosophical practice of pragmatism and evolving to maintain its independence as a linguistic subfield by keeping to its tract of being practical in treating the everyday concerned meaning.

\section{Methodology}

This paper is a qualitative analytical study. The researcher attended three (3) selected Meranaw weddings to collect data. Three 3 speeches from different speakers were also selected as part of the data collection. Interviews with old Meranaw folks for the validation of the interpretations were also done. The researcher uses semiotic analytical approach in the interpretations of data. 


\section{Results and discussions}

1. What pragmatic skills are present in the collected speech acts of Meranaw weddings in terms of:

\section{a) Verbal}

\section{Greetings/Acknowledgments}

Speeches are usually started with greetings. Greetings take too much time because of the positive adjectives used to describe and acknowledge very important persons in the event.

"so pakatatayaan ami a pagari ami a malai limo ago tindeg ko mga tonganay niyan. So lukes tano a pakatatalingomaan a konseyal sa engkaya inged tano a masiu a paparatiyayaan a sulutan a gaus sa masiu a si sulutan ".

Translation:

To our most beloved brother who has generosity and pride for his relatives, our incoming councilor to this prestigious hometown named Masiu, our followed Sultan a Gaus of Masiu, Sultan

In many meranaw occasions, it is expected that the master of ceremony will acknowledge selected people as recognition. When these people are not acknowledged, they usually turn their backs off the event as their own way of showing their dismay and disappointment for not being recognized. In the other way around, when the master of ceremony was not able to recognize these people, he has to certainly extend an apology.

\section{Request}

"sii ko kapakamamasa o mga tonganay o mga kababayan ago so mga kamamaan, na sekaten ami so lantong ami a 10,000php a para ko mga ngongoda ago so leka sa paitaw a 10,000php a rekon o mga raga"

Translation:

In the presence of the relatives of the bride and groom, we are asking for our lantong (cultural practice of asking an amount of money from the groom for the bride's male relatives) amounting to 10,000 pesos for the bachelors and leka sa paitaw or opening of door (cultural practice of asking an amount of money from the groom for the bride's female relatives for them to open the door for the groom to see his bride) amounting to 10,000 pesos for the ladies.

These issues on the wedding ceremony usually come out before the groom finally sees and fetches the bride. Family members ask for amounts as their share or "adat". In some cases, marriage ceremonies comes to failure because some interprets this gesture as a way of saying no and not acceptance of the grooms family on side of the woman. In some cases, the groom's family would choose not to pursue with the event because of the gesture. For some, when the woman's family asks something that is too difficult to be provided by the groom's family, they consider is as way of rejecting the groom.

\section{Responses}

Responses can be very sensitive. Before the woman's family will finally accept the groom and finalize the wedding schedule, the bride is usually asked whether they will accept the man or not. In some interviews, here are some of the ways bride asnwered their parents' question.

"sekanoden, o kababayaan iyo na kababayaan aken mambo"

Translation: It depends to your decision, if you like him then, I like him too"

"Mingginawai kami ago gyanan a mama na para raken na mapiya sekaniyan a ginawai"

Translation: The man is my friend and for me he is a good person.

"O mananaguntaman a gyanan a mama na iyogi niyoden"

Translation: If the man is determined then accept him.

"Asara mibtad iyan so mahar na iyogi niyoden"

Translation: If he can afford the dowry then you can accept him.

"da katawan aken a kipaawing aken sa gyanan a mama"

Translation: I don't see any flaw from that man. 
This are very indirect responses of saying "Yes, I will accept the man as my husband". In Meranaw, it is "mawag" or unethical for a bride to be to vocally say yes when asked because it may mean "too much excitement" "liberated" and "no breeding". Thus, women usually say it in a way their parents would best understand it as acceptance.

\section{Using Humor}

Humor in Meranaw is a very democratic way of giving responses without offending other parties. In some way, humor is sarcasm. Thus, it will take a man to fully understand and interpret a language. For example:

Ba opon mikilat na minitayak a tae!

Translated: It's not because there is lighting then you'll see feces all over.

This is a humor in Meranaw but this is another way of saying "not all that is said should be taken seriously. In the Meranaw weddings, when some members are gining humuros stunts, people may consider it as a gesture of acceptance and happiness. Humor can be completely an opposite of silence.

\section{b) Non-verbal}

Speeches are usually started with greetings. In certain occasions, when you greet someone without any response it means rejection. When a woman pouts its lips when asked for a response it means rejection. In wedding ceremonies, when a bride is asked for agreement, silence may mean yes. In the same way, requests are also showed in these manners.

Intonation can also be non-verbal pragmatic skills. Meranaw intonation can mean similar to others. When the pitch and intonation is very high it suggests anger, dissatisfaction or rejection while a lower tone means calmness, acceptance and dignified.

\section{Conclusion}

Like any other languages in the world, the Meranaw language also has its unique features that is only understandable by people who have lived with the Meranaw language speakers. From the findings of the study, we have unveiled the use of pragmatics in Meranaw weddings both in verbal and non-verbal ways. The study shows how the Meranaw people use their language to communicate their culture. As shown from the findings of the study, the Meranaw people are honorific, appreciative, and conservative. The role of woman as reserved, family oriented and obedient are also visible in the way they use their language. Thus, to better understand the Meranaw people and build a healthy relationship with them, one has to immerse himself or herself with the folks to fully understand what a word means and or a gesture means.

Pragmatic skills are indeed a challenge to communication. Sometimes, communication problems arises due to misinterpretations or misunderstandings brought by cultural and language differences. Hence, pragmatic competence should be considered in building bridges across the different nations of the world. Understanding a person is not only limited to his or her physical or visible culture. There is more of himself or herself from what lies beyond.

Funding: This research received no external funding.

Acknowledgments: The author would like to acknowledge the editorial board of the International Journal for Language, Literature and Translation (IJLLT) for the opportunity given to researchers of the field.

Conflicts of Interest: The author declares no conflict of interest.

\section{References}

[1] Austin, J.L. (1962 A) How to Do Things with Words.Oxford: Clarendon Press.

[2] Belinda Hills Associates. Pragmatic Language.pdf. Accessed April 2016

[3] Eales, M. J. (1993) Pragmatic impairments in adults with childhood diagnoses of autism or developmental receptive language disorder. Journal of Autism and Developmental Disorders, 23,593-617. doi:10.1007/BF01046104.

[4] Kasper, G., (1997). Can pragmatic competence be taught?', paper delivered at the 1997 TESOL Convention.

[5] Kristine D. and, Parina, J. (N.D). A Study of Filipino Complaints in English and Tagalog.pdf. Accessed April 2016

[6] Leech, G., (1983). Principles of Pragmatics. London, Longman.

[7] Leinonen, E. K., Ryder, N., Ellis, M. \& Hammond, C. (2003). The use of context in pragmatic comprehension by specifically languageimpaired and control children. Linguistics, 41 (2), 407-423.

[8] Searle, J.R. (1969). Speech Acts. Cambridge: CUP.

[9] Shaozhong, L (N.D). What is Pragmatics? www.pragliu.web.prog.com. Accessed April 2016.

[10] Social Research Glossary (quality research international), www.qualityresearchinternation.al.com/. Accesed April 2021

[11] Sperber, D. \& Wilson, D., (1986). Relevance: Communication and cognition, Oxford, Blackwell. 